\title{
DETEKSI PEMALSUAN CITRA DENGAN TEKNIK COPY-MOVE MENGGUNAKAN METODE ORDINAL MEASURE DARI KOEFISIEN DISCRETE COSINE TRANSFORM
}

\author{
Zulfan*, Fitri Arnia dan Rusdha Muharar \\ Jurusan Teknik Elektro, Fakultas Teknik, Universitas Syiah Kuala \\ *Corresponding author, e-mail : zulfanzainal@yahoo.co.id
}

\begin{abstract}
Abstrak - Artikel ini membahas tentang metode baru untuk deteksi citra palsu yang dihasilkan dari teknik copy-move. Teknik copy-move merupakan salah satu teknik pemalsuan citra dengan cara mengambil objek tertentu dari citra asli dan menambahkannya pada citra tersebut dengan tujuan untuk menambah jumlah atau merubah objek yang sama pada citra asli. Penelitian ini bertujuan untuk mendeteksi citra palsu yang dihasilkan oleh teknik copy-move dan citra palsu copy-move yang telah dimodifikasi dengan operasi rotasi dan ekualisasi histogram. Fitur deteksi yang digunakan adalah Ordinal Measure dari koefisien Discrete Cosine Transform (OM-DCT). Pendeteksian dimulai dengan membagi citra ke dalam blok berukuran $\mathrm{BxB}$ (B = 16x16, 32x32 dan 64x64) dan DCT 2 dimensi dilakukan pada setiap blok tersebut. Jarak fitur citra asli dengan palsu dihitung dengan persamaan jarak Ecluidian dan setiap fitur yang memiliki jarak lebih kecil atau sama dengan nilai threshold $(\mathrm{T})$ menurut pengamatan akan ditandai sebagai bagian yang dipalsukan. Hasil pendeteksian menunjukkan bahwa ada blok-blok yang terdeteksi pada objek citra yang di-copy-move baik pada citra palsu copy-move yang tidak dimodifikasi ataupun yang telah dimodifikasi dengan operasi rotasi dan ekualisasi histogram. Jumlah blok yang ditemukan pada objek copy-move bervariasi sesuai ukuran blok pendeteksian yang digunakan.
\end{abstract}

Kata kunci : Discrete Cosine Transform (DCT), ordinal measure dari koefisien DCT, copy-move, rotasi, ekualisasi histogram.

\begin{abstract}
This article discusses a new method for the detection of forgery images generated by copy-move technique. Copy-move technique is one of image forgery techniques which taking a particular object from its original image and add it on that image for the purpose of increasing the number of or changing the same object in the original image. This study aims to detect the forged image generated by the copy-move techniques and copy-move forged image that has been modified by the rotation operation and histogram equalization. Detection feature used is Ordinal Measure of Discrete Cosine Transform coefficient (OM-DCT). Detection starts with division of the image into a block size of $\mathrm{BXB}(\mathrm{B}=16 \times 16,32 \times 32$ and $64 \times 64)$ and two-dimensional DCT was performed to each of blocks. The feature distance from the original to the fake image, was calculated by the Euclidian distance and each feature has a distance of less than or equal to the threshold value (T) according to the observations will be marked as a forged part. The results show that there are blocks detected on the copy-move image, whether on the unmodified copy-move forge image or those which modified by the rotation operation and histogram equalization. The number of blocks that are found in the copy-move object varies according to the size of the detection block used.
\end{abstract}

Key words: Discrete Cosine Transform (DCT), ordinal measure of DCT Coefficient, copy-move, rotation, histogram equalization.

Copyright () 2016 JNTE. All rights reserved

\section{PENDAHULUAN}

Citra merupakan representasi dari suatu objek atau kejadian. Sebelum berkembangnya teknologi pengolahan citra digital, kita mengenal citra hanya dalam bentuk analog saja. Akan tetapi dengan berkembangnya teknologi digital saat ini, peredaran citra dalam bentuk digital terus meningkat. Citra digital lebih dinamis dan dapat diubah-ubah (editable) baik dari segi bentuk, ukuran maupun objek yang ada dalam citra digital tersebut. Hal ini tentunya akan sangat mempengaruhi keanekaragaman citra digital yang muncul di masyarakat sehingga mengakibatkan sulitnya membedakan antara citra yang asli atau palsu. Kemunculan citra-citra digital seperti ini akan menimbulkan permasalahan dalam kehidupan sosial 
masyarakat seperti hilangnya kepercayaan terhadap suatu berita, perusakan terhadap reputasi seseorang, pemalsuan barang bukti dan banyak permasalahan lainnya [1].

Pemalsuan terhadap citra digital sangat mungkin terjadi di era digital saat ini. Hal ini disebabkan oleh banyaknya perangkat foto digital dan aplikasi pengolahan citra yang dikembangkan sehingga seseorang dapat dengan mudah mengambil dan memodifikasi suatu citra digital tanpa meninggalkan jejak yang dapat ditelusuri. Berbagai teknik pemalsuan dapat dilakukan untuk menghasilkan citra palsu yang sulit untuk dideteksi. Salah satu teknik pemalsuan yang dapat digunakan adalah teknik pemalsuan copy-move [2]. Teknik pemalsuan ini dilakukan dengan cara menyalin objek tertentu pada citra asli dan menambahkannya pada bagian tertentu pada citra yang sama dengan tujuan untuk memperbanyak jumlah objek pada citra ataupun untuk menyembunyikan objek tertentu yang terdapat pada citra asli [3][1]. Gambar 1 merupakan contoh citra palsu yang dihasilkan dengan teknik copy-move. Citra palsu tersebut dihasilkan dengan cara menduplikasi objek pesawat asli dan meletakkannya pada sisi kiri objek asli sehingga antara citra asli dan palsu akan sulit dibedakan. Hal ini tentunya akan dapat merusak keaslian sebuah citra dan menurunkan kepercayaan masyarakat jika dijadikan sebagai sebuah berita.

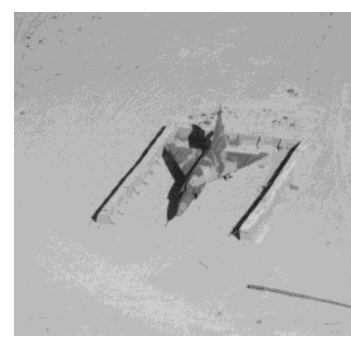

a. Citra Original

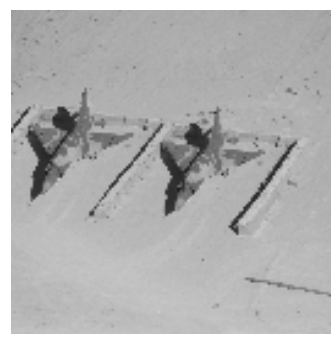

b. Citra palsu
Gambar 1. Contoh pemalsuan citra copy-move

Dengan adanya berbagai teknik pemalsuan, maka sangat diperlukan pengembangan metode pendeteksian yang cukup baik untuk mendeteksi citra palsu yang dihasilkan. Secara umum, metode pendeteksian yang dikembangkan ada dua yaitu metode aktif dan pasif [1]. Metode aktif merupakan metode deteksi dengan cara memanfaatkan watermarking [4] dan digital signature yang dimasukkan ke dalam citra pada saat sebuah citra diciptakan [2]. Metode pasif merupakan metode deteksi yang tidak menggunakan informasi tambahan yang dimasukkan ke citra karena pendeteksian dilakukan dengan mengindentifikasi perubahan fitur [2]. Penelitian ini menggunakan metode pasif dan fitur yang digunakan untuk pendeteksian adalah Ordinal Measure koefisien Discrete Cosine Transform (OM-DCT).

Metode pendeteksian citra palsu copy-move pertama kali diusulkan oleh J.Fridrich et.al [3] dengan menggunakan nilai koefisien Discrete Cosine Transform (DCT) sebagai fitur pendeteksian. Pada penelitian mereka, nilai koefisien DCT diektraksi dari citra dengan melakukan pembagian citra ke dalam blok-blok citra berukuran 16x16. Nilai koefisien DCT yang telah diektraksi dari masing-masing blok dikuantisasi terlebih dahulu sebelum proses pendeteksian dilakukan. Hasil penelitian menunjukkan bahwa nilai koefisien DCT dapat digunakan untuk melakukkan pendeteksian pada citra palsu copy-move, akan tetapi fitur ini tidak cukup baik apabila ingin mendeteksi citra palsu yang telah dimodifikasi dengan operasi geometri [1]. Penelitian menggunakan ordinal measure koefisien Discrete Cosine Transform sebagai fitur pendeteksian. Fitur ini dianggap lebih tahan terhadap operasi geometri [5]. Fitur ini sudah pernah digunakan oleh C.Kim [5] untuk pendeteksian duplikasi citra digital dalam kasus image retrival dan F.Arnia [6] untuk perbaikan pencocokan iris.

\section{TINJAUAN PUSTAKA}

Teknik pemalsuan copy-move merupakan salah satu cara yang sangat efektif dalam pemalsuan citra karena hanya menduplikasi bagian tertentu pada citra yang sama sehingga karakteristik dari bagian-bagian yang di-copymove memiliki kecocokan [1]. Copy-move juga dapat diartikan sebagai teknik pemalsuan citra dengan mengambil bagian dari citra untuk menutupi objek-objek tertentu pada citra yang sama [3].

Citra yang telah dipalsukan dengan teknik ini dapat dimodifikasi dengan dua kelompok Citra yang telah dipalsukan dengan teknik ini dapat dimodifikasi dengan dua kelompok operasi pengolahan citra sehingga menghasilkan citra palsu yang sulit untuk 


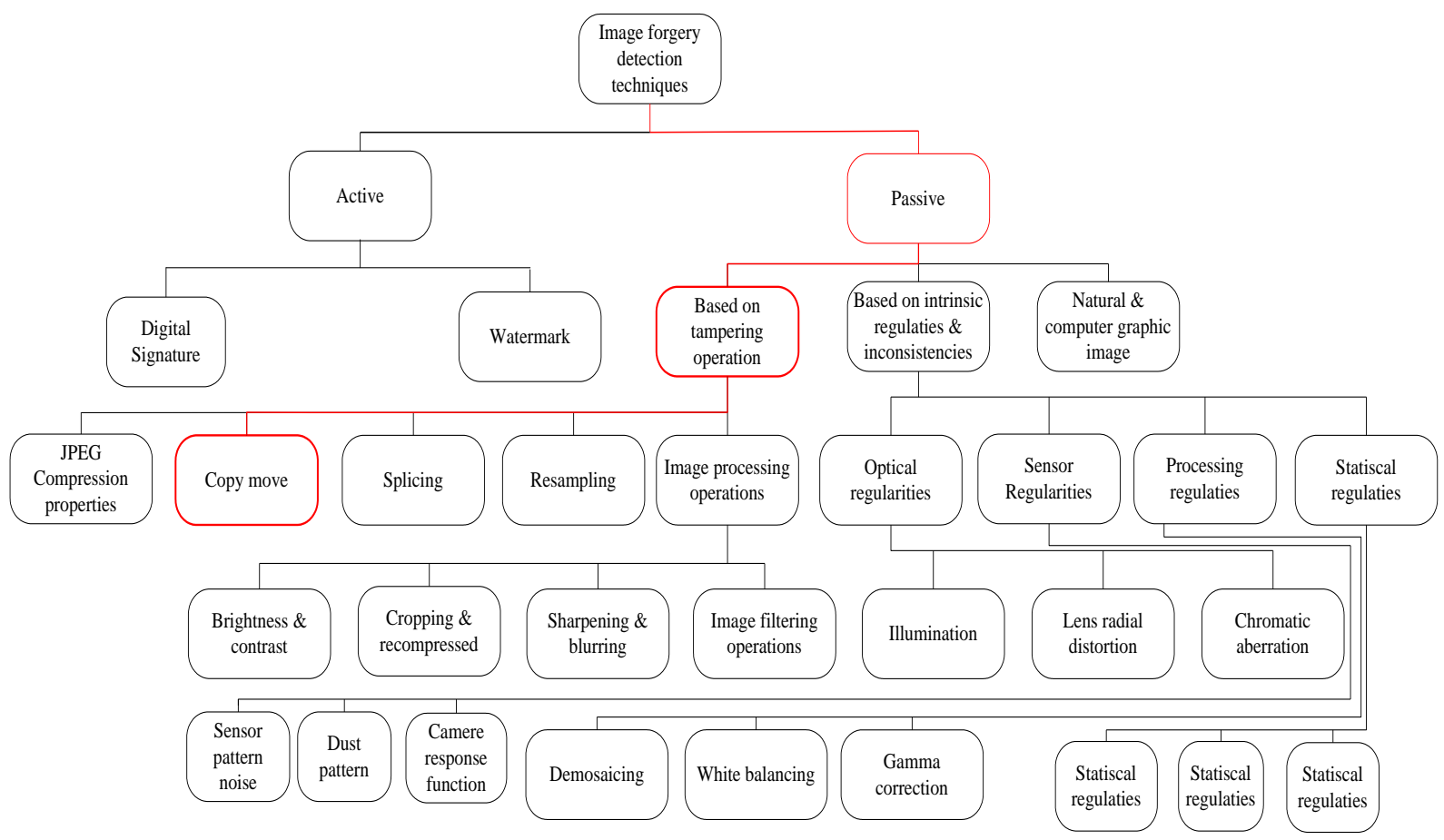

Gambar 2. Klasifikasi Teknik Deteksi Pemalsuan Citra Digital [1]

dideteksi (Gambar 3). Operasi tersebut yaitu operasi post-processing dan operasi skala menengah (Intermediate Operation). Pada operasi post-processing, kompresi JPEG, tambahan noise serta blurring dilakukan untuk menghilangkan jejak operasi copy-move sehingga sulit untuk dideteksi. Operasi skala menengah (Intermediate Operation) dilakukan untuk menghasilkan sinkronisasi spasial dan kemiripan antara bagian copy-move dengan bagian yang asli. Operasi ini dapat berupa operasi rotasi, scaling, pencerminan dan modifikasi pencahayaan [1]. Citra merupakan representasi dari suatu kenyataan tentang sebuah kejadian.Citra harus memiliki integritas yang tinggi apabila ingin dijadikan sebagai sebuah barang bukti [1]. Pembuktian keaslian pada citra yang dijadikan sebagai barang bukti harus dilakukan agar diperoleh suatu informasi yang akurat dan dapat dipertanggung- jawabkan. Hal ini telah memberi kontribusi para peneliti di bidang forensik citra digital untuk terus melakukan penelitian dan menciptakan algoritma-algoritma pendeteksian yang handal. Secara umum, ada dua metode yang digunakan untuk pendeteksian yaitu metode deteksi aktif dan pasif. Klasifikasi dari dua metode tersebut disajikan pada Gambar 2.

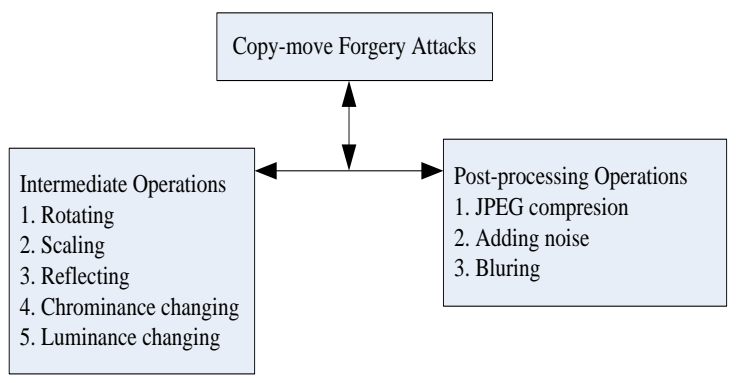

Gambar 3. Operasi pemalsuan copy-move [1]

Deteksi pemalsuan dengan metode aktif adalah teknik deteksi dengan memanfaatkan kode-kode autentifikasi seperti watermarking atau digital signature yang dimasukkan ke dalam citra digital sebelum disebarluaskan sehingga deteksi pemalsuan dapat dilakukan dengan membandingkan kode-kode dalam citra yang dipalsukan dengan kode-kode dalam citra asli [2].

\section{METODOLOGI}

Terdapat dua tahapan yang dilakukan untuk mendeteksi objek citra palsu copy-move dengan metode ini yaitu tahap pelatihan (training) dan pengujian (testing). Ordinal Measure DCT digunakan sebagai fitur dalam metode pendeteksian ini. Skema pelatihan ditunjukkan 
pada Gambar 4, beberapa citra masukkan (citra asli) di-input ke dalam simulator dan dibagi menjadi blok citra dengan ukuran $m \times n$.Setiap blok citra ditransformasikan ke bentuk DCT dua dimensi untuk mengektraksi fitur citra. Nilai koefisien DC dari nilai DCT pada citra dihilangkan sehingga yang tertinggal hanya nilai koefisien ACnya saja. Koefisien AC inilah yang dijadikan sebagai fitur untuk pendeksian. Fitur citra ini disebut dengan Ordinal Measure DCT (OM-DCT).

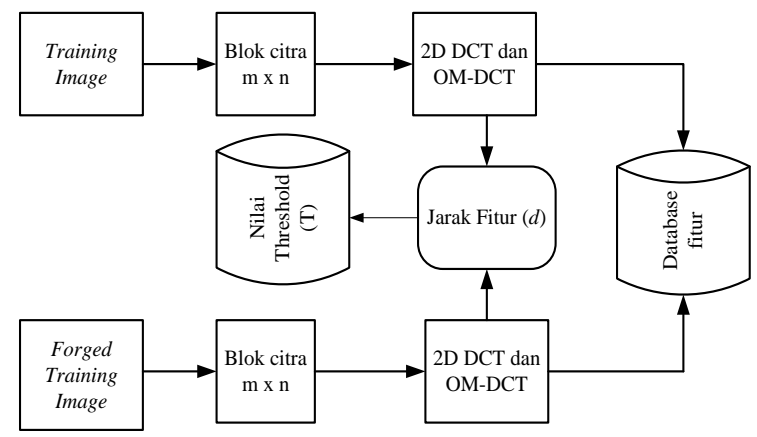

Gambar 4. Metode pelatihan.

Nilai fitur normalisasi akan diurutkan dari nilai minimum hingga maksimum. Sebanyak 10 set nilai fitur vektor terkecil akan diambil dan dijadikan nilai referensi untuk pendeteksian pada tahap pelatihan. Penentuan nilai threshold (T) pada tahap ini dilakukan dengan mengambil nilai maksimum dari 10 set nilai fitur vektor tersebut. Tahapan berikutnya adalah tahap pengujian (testing). Pada tahap ini sekelompok citra yang telah dipalsukan akan diujicoba dengan melakukan langkah-langkah seperti pada Gambar 5. Jarak fitur citra asli dengan citra palsu akan dihitung dengan menggunakan persamaan jarak Ecluidian [7]. Pada tahap pengujian, nilai jarak fitur OM-DCT yang diperoleh akan dinormalisasi terlebih dahulu. Proses normalisasi dilakukan dengan membagi setiap nilai fitur yang didapat dengan nilai fitur maksimum sehingga nilai normalisasi yang diperoleh adalah $\leq 1$.

Bahan penelitian yang digunakan adalah citra original (Gambar 6), citra yang telah dipalsukan dengan teknik copy-move untuk pelatihan (Gambar 7) dan citra palsu copy-move untuk pengujian (Gambar 8). Citra asli merupakan citra grayscale yang digunakan sebagai citra referensi untuk pendeteksian dengan ukuran $512 \times 512$.

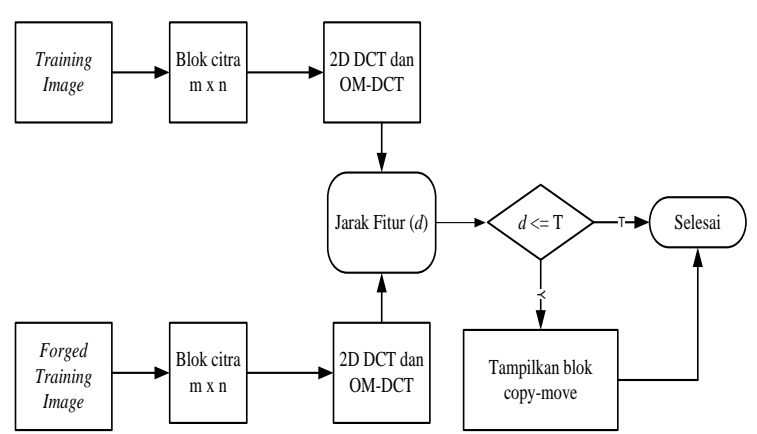

Gambar 5. Metode Pengujian
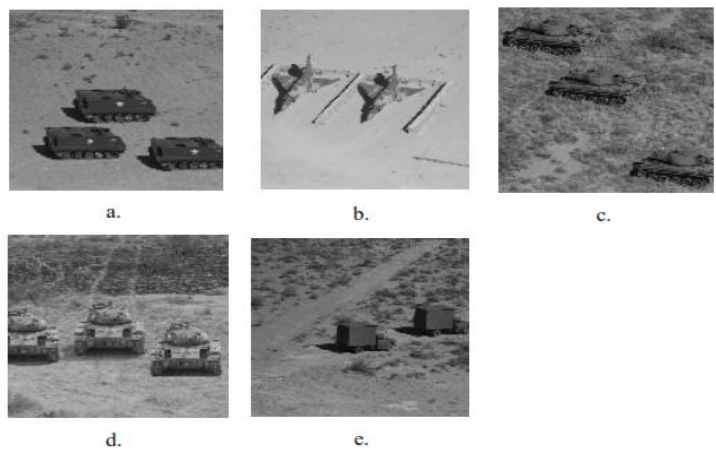

Gambar 6. Citra original sebagai citra referensi
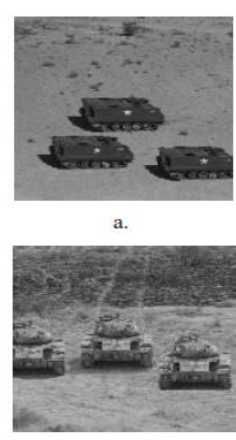

d.

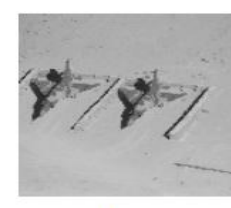

b.

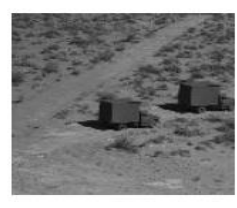

e.

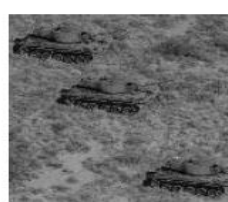

c.
Gambar 7. Citra palsu untuk pelatihan.

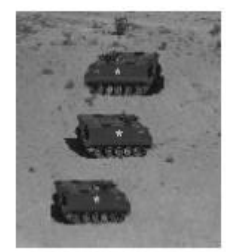

a.

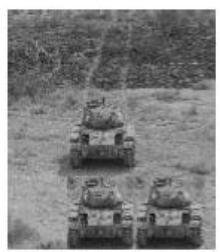

b.

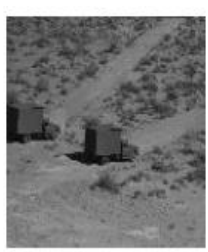

c.
Gambar 8. Citra palsu untuk pengujian.

Gambar 8 merupakan citra-citra palsu yang digunakan pada saat pengujian. Citra-citra tersebut adalah (a) BaracudaCopy.tif, (b) TankCopy.tif dan (c) TrukCopy.tif. 


\section{HASIL DAN PEMBAHASAN}

Hasil penelitian diperoleh dari pengujian terhadap 5 kelompok citra yang telah dipalsukan dengan teknik copy-move dan juga dimodifikasi dengan operasi rotasi [8] dan histogram ekualisasi. Pengujian juga dilakukan dengan menggunakan blok pendeteksian berukuran $64 \times 64,32 \times 32$ dan $16 \times 16$. Nilai ambang batas yang digunakan untuk pendeteksian adalah 0.4 .

\subsection{Pengujian Citra copy-move tanpa modifikasi.}

Pada pendeteksian ini digunakan sebanyak 3 set citra palsu copy-move yang tidak dimodifikasi dengan operasi rotasi ataupun ekualisasi histogram. Hasil pendeteksian ditunjukkan pada Gambar 9, 10 dan 11. Berdasarkan gambar dapat dilihat bahwa pendeteksian yang dilakukan pada citra palsu copy-move yang tidak dimodifikasi diperoleh blok-blok yang terdeteksi pada objek copy-move pada citra palsu. Jumlah blok yang terdeteksi pada objek copy-move berbeda-beda sesuai dengan ukuran blok yang digunakan. Jika menggunakan blok berukuran $64 \times 64$ maka jumlah blok terbanyak yang terdeteksi pada objek copy-move adalah pada citra palsu TankCopy.tif dan jika menggunakan blok berukuran 32x32 dan 16x16, jumlah blok terbanyak yang terdeteksi pada objek copy-move adalah pada citra palsu BaracudaCopy.tif
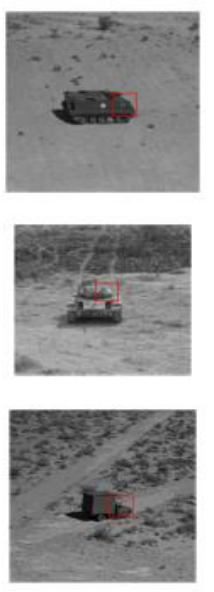

a. Citra Original
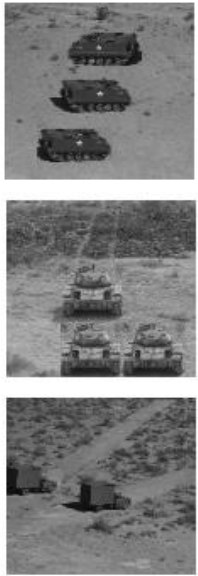

b. Citra palsu
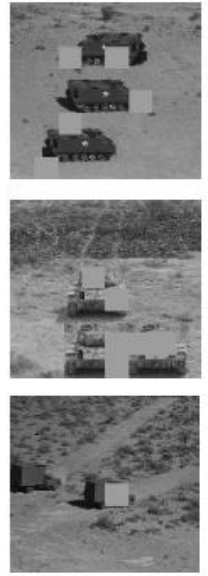

c. Hasil pendeteksian
Gambar 9. Hasil pengujian citra palsu copymove tanpa modifikasi dengan blok $64 \times 64$.
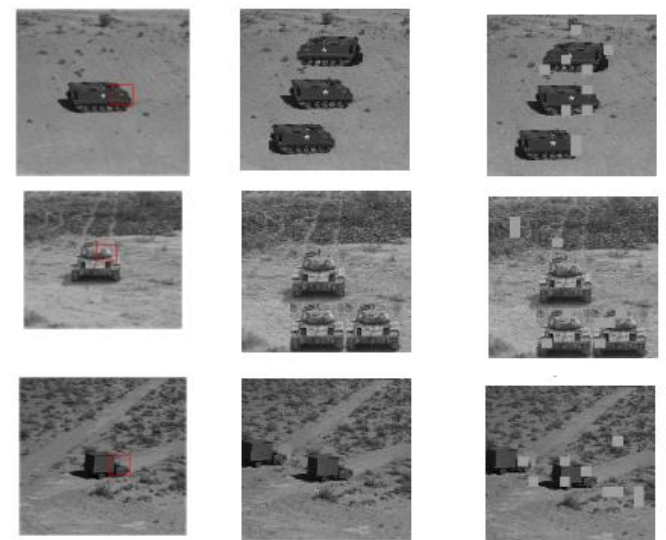

a. Citra Original

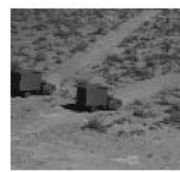

b. Citra palsu

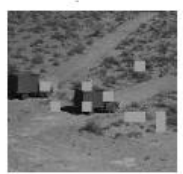

c. Hasil pendeteksian

Gambar 10. Hasil pengujian citra palsu copymove tanpa modifikasi dengan blok $32 \times 32$.
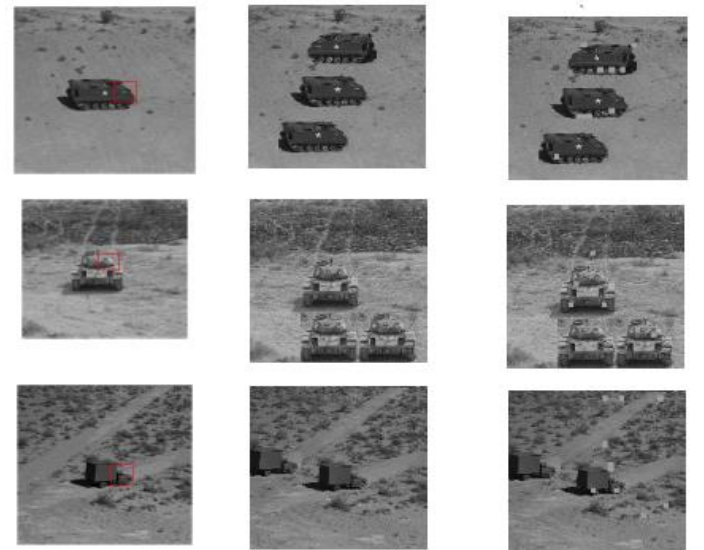

a. Citra Original
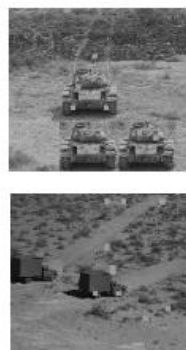

c. Hasil pendeteksian

Gambar 11. Hasil pengujian citra palsu copymove tanpa modifikasi dengan blok $16 \times 16$.

\subsection{Pengujian citra copy-move dengan modifikasi rotasi (vertical flipping) \\ Pada pendeteksian ini digunakan sebanyak} 3 set citra palsu copy-move yang telah dimodifikasi dengan operasi rotasi (vertical flipping). Hasil deteksi ditunjukan pada gambar 12, 13 dan 14. Hasil pendeteksian pada kelompok citra ini menunjukkan bahwa jika menggunakan blok pendeteksian berukuran 64x64 ditemukan blok terbanyak yang terdeteksi pada objek copy-move terjadi pada citra palsu TankCopyFlid.tif. Jika menggunakan blok pendeteksian berukuran 32×32 dan 16×16 maka jumlah blok terbanyak yang terdeteksi pada objek copy-move terjadi pada citra BaracudaCopyFlid.tif 

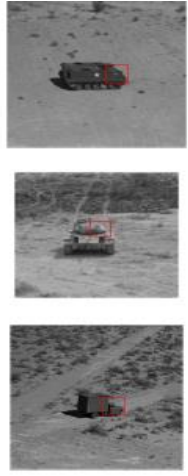

a. Citra Original
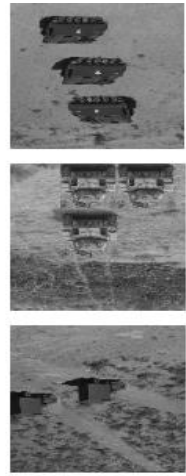

b. Citra palsu
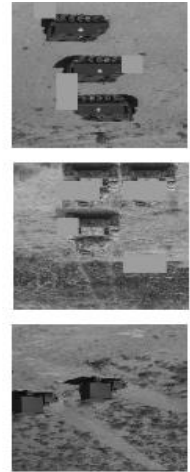

c. Hasil pendeteksian
Gambar 12. Hasil pengujian citra palsu copymove termodifikasi rotasi (vertical flipping) dengan blok $64 \times 64$.
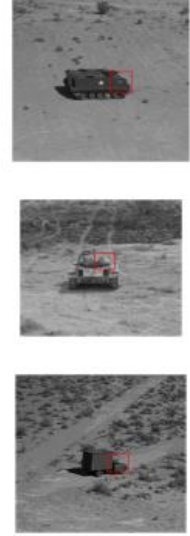

a. Citra Original
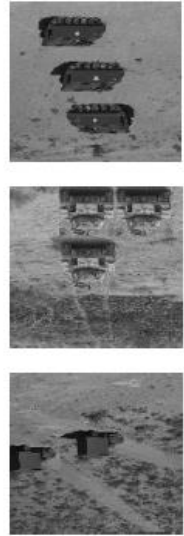

b. Citra palsu
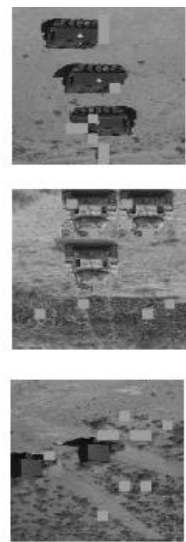

c. Hasil pendeteksian

Gambar 13. Hasil pengujian citra palsu copymove termodifikasi rotasi (vertical flipping) dengan blok $32 \times 32$.
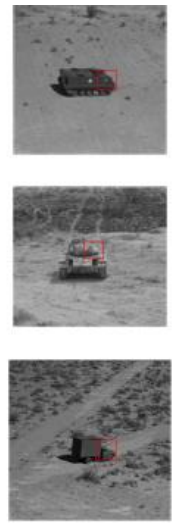

a. Citra Original
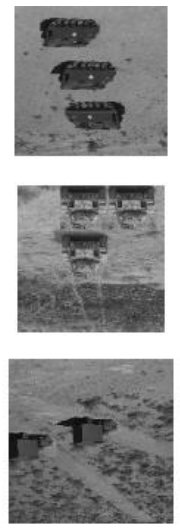

b. Citra palsu
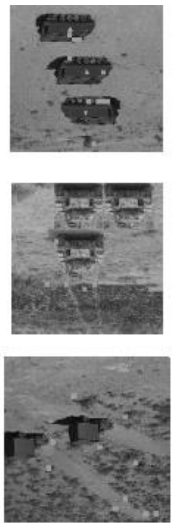

c. Hasil pendeteksian
Gambar 14. Hasil pengujian citra palsu copymove termodifikasi rotasi (vertical flipping) dengan blok $16 \times 16$.
4.3. Pengujian citra copy-move dengan modifikasi rotasi (horizontal flipping)

Pada pendeteksian ini digunakan sebanyak 3 set citra palsu copy-move yang telah dimodifikasi dengan operasi rotasi (horizontal flipping). Hasil deteksi ditunjukan pada Gambar 15,16 dan 17. Jumlah blok yang paling banyak terdeteksi jika menggunakan blok pendeteksian berukuran 64x64 terdapat pada citra palsu TankCopyFlir.tif jika menggunakan blok berukuran $32 \times 32$ dan $16 \times 16$ terdapat pada citra palsu BaracudaCopyFlir.tif.
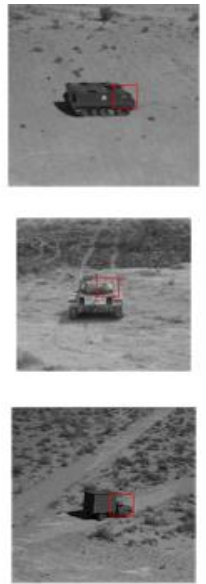

a. Citra Original
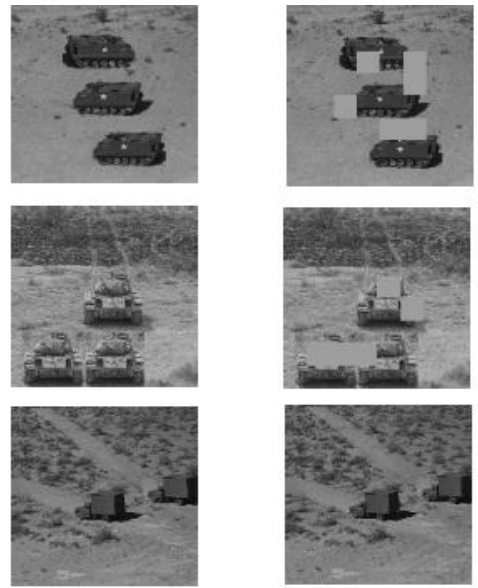

b. Citra palsu
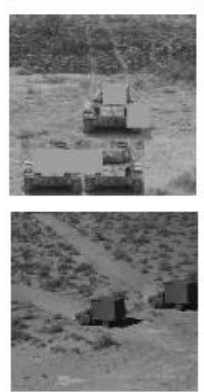

c. Hasil pendeteksian
Gambar 15. Hasil pengujian citra palsu copymove termodifikasi rotasi (horizontal flipping) dengan blok $16 \times 16$.
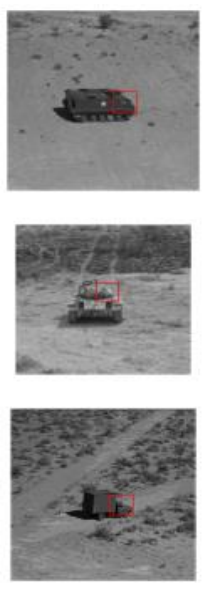

a. Citra Original
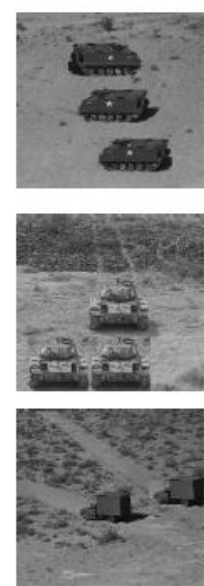

b. Citra palsu
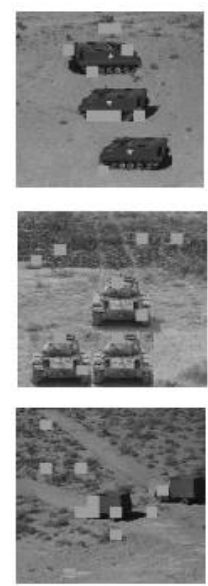

c. Hasil pendeteksiar
Gambar 16. Hasil pengujian citra palsu copymove termodifikasi rotasi (horizontal flipping) dengan blok $32 \times 32$. 

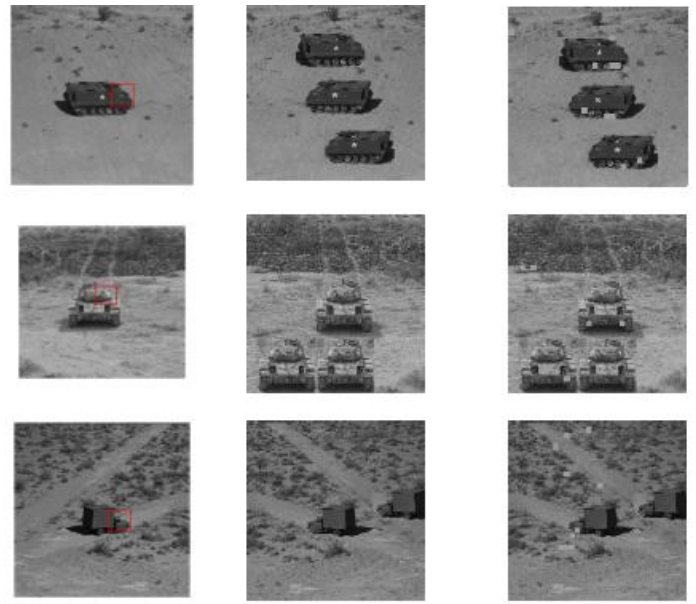

a. Citra Original

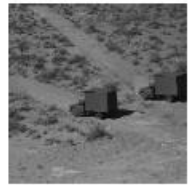

b. Citra palsu
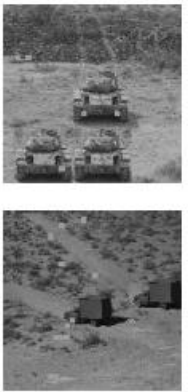

c. Hasil pendeteksian

Gambar 17. Hasil pengujian citra palsu copymove termodifikasi rotasi (horizontal flipping) dengan blok $16 \times 16$.

\subsection{Pengujian citra copy-move dengan modifikasi rotasi $90^{\circ}$ \\ Pada pendeteksian ini digunakan sebanyak} 3 set citra palsu copy-move yang telah dimodifikasi dengan operasi rotasi $90^{\circ}$. Hasil deteksi ditunjukan pada Gambar 18, 19 dan 20. Jumlah blok yang paling banyak terdeteksi terjadi pada citra BaracudaCopyRot.tif. Hasil ini diperoleh berdasarkan penggunaan blok deteksi berukuran $64 \times 64,32 \times 32$ dan 16x16.
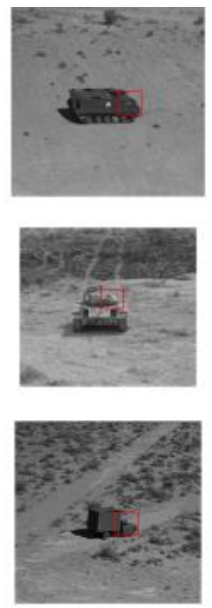

a. Citra Original
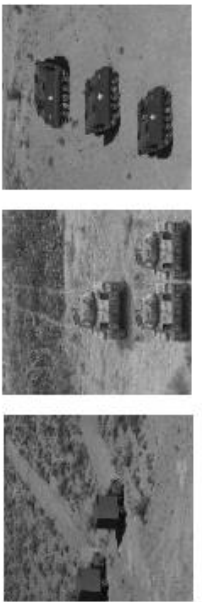

b. Citra palsu
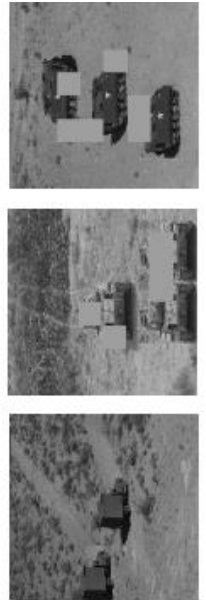

c. Hasil pendeteksian

Gambar 18. Hasil pengujian citra palsu copymove termodifikasi rotasi $90^{\circ}$ dengan blok $64 \times 64$.
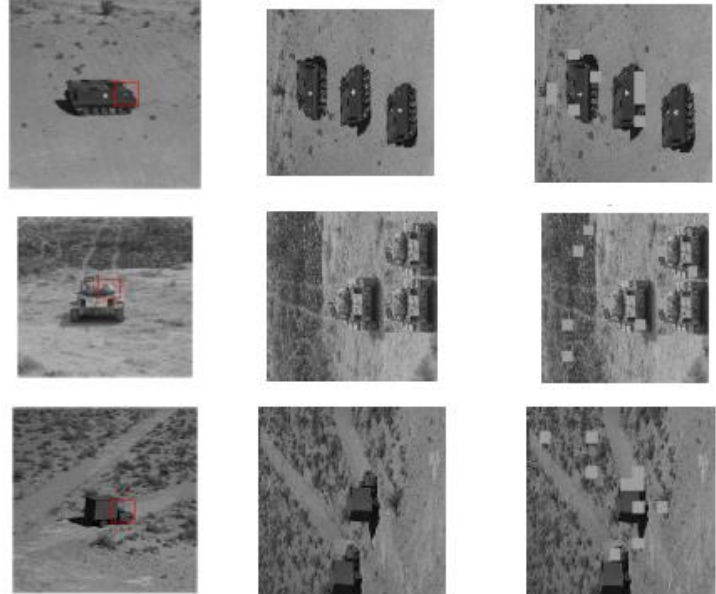

a. Citra Original

b. Citra palsu

c. Hasil pendeteksian

Gambar 19. Hasil pengujian citra palsu copymove termodifikasi rotasi $90^{\circ}$ dengan blok $32 \times 32$.
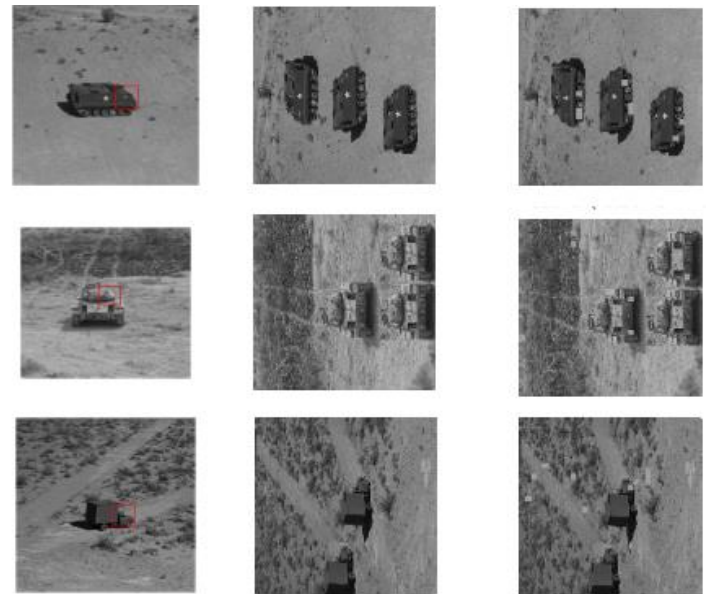

a. Citra Original

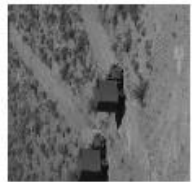

b. Citra palsu
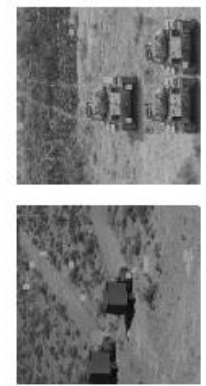

c. Hasil pendeteksian
Gambar 20. Hasil pengujian citra palsu copymove termodifikasi rotasi $90^{\circ}$ dengan blok $16 \times 16$.

\subsection{Pengujian citra Copy-move dengan modifikasi ekualisasi histogram.}

Pada pendeteksian ini digunakan sebanyak 3 set citra palsu copy-move yang telah dimodifikasi dengan operasi ekualisasi histogram. Hasil deteksi ditunjukan pada gambar 21, 22 dan 23. Hasil pendeteksian menunjukkan bahwa jumlah blok yang ditemukan pada objek copy-move sangat sedikit dibandingkan dengan pendeteksian pada kelompok citra sebelumnya. Blok citra yang terdeteksi pada objek copy-move ditemukan pada citra palsu BaracudaCopyHist.tif. 

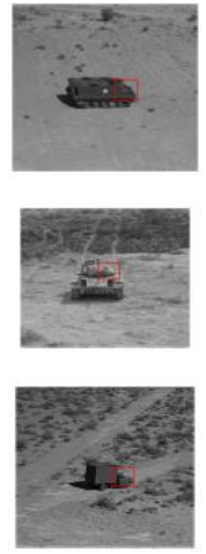

a. Citra Original
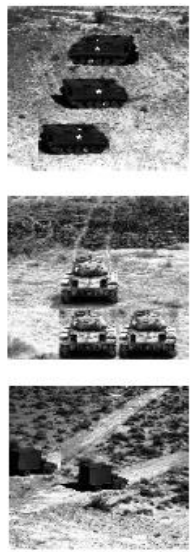

b. Citra palsu
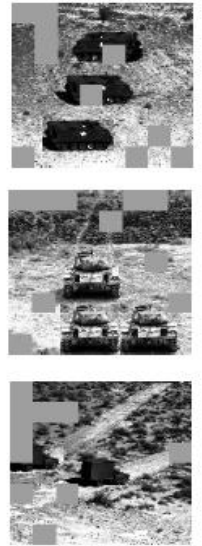

c. Hasil pendeteksian
Gambar 21. Hasil pengujian citra palsu copymove termodifikasi ekualisasi histogram dengan blok $64 \times 64$.
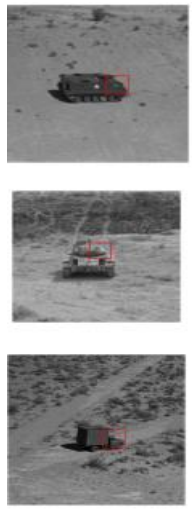

เ. Citra Original
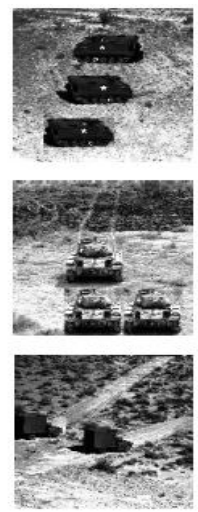

b. Citra palsu
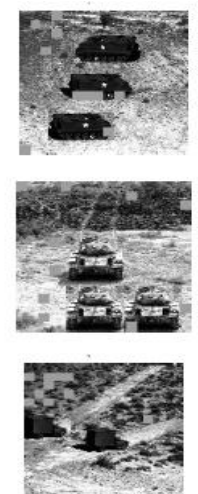

c. Hasil pendeteksia
Gambar 22. Hasil pengujian citra palsu copymove termodifikasi ekualisasi histogram dengan blok $32 \times 32$.
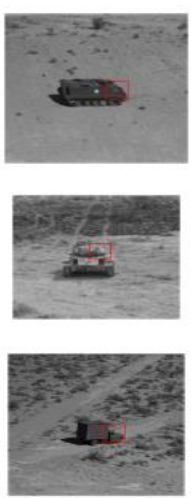

a. Citra Original
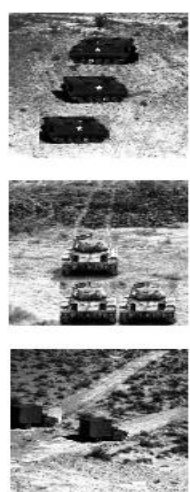

b. Citra palsu
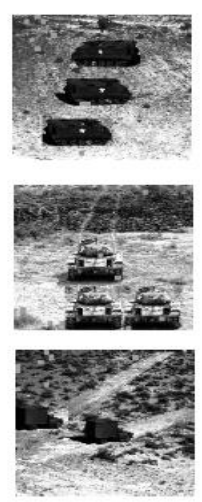

c. Hasil pendeteksian
Gambar 23. Hasil pengujian citra palsu copymove termodifikasi ekualisasi histogram dengan blok $16 \times 16$.
Hasil penelitian menunjukkan bahwa penggunaan ordinal measure DCT sebagai fitur pendeteksian telah mampu mendeteksi objek copy-move pada sebuah citra yang dipalsukan dengan teknik copy-move. Fitur juga dapat digunakan untuk mendeteksi pemalsuan pada citra copy-move yang telah dimodifikasi dengan operasi rotasi dan ekualisasi histogram. Kemampuan fitur untuk pendeteksian dibuktikan dengan adanya blok-blok yang ditandai pada objek citra copy-move dimana blok-blok citra yang ditandai tersebut merupakan blok yang memiliki jarak fitur lebih kecil dari nilai ambang batas. Jumlah blok yang terdeteksi pada objek copy-move bervariasi sesuai dengan ukuran blok pendeteksian yang digunakan. Jumlah blok yang terdeteksi pada objek copy-move berdasarkan penggunaan ukuran blok disajikan dalam tabel-tabel di bawah ini.

Tabel 1. Hasil deteksi pada citra copy-move

\begin{tabular}{|c|c|c|c|}
\hline \multirow{2}{*}{ Citra Palsu } & \multicolumn{4}{|c|}{$\begin{array}{c}\text { Jumlah blok terdeteksi pada } \\
\text { objek copy-move (ukuran blok } \\
\end{array}$} & \multicolumn{3}{|c|}{ berbeda) } \\
\cline { 2 - 4 } & $64 \times 64$ & $32 \times 32$ & $16 \times 16$ \\
\hline BaracudaCopy.tif & 4 & 6 & 5 \\
\hline TankCopy.tif & 4 & 6 & 1 \\
\hline TrukCopy.tif & 0 & 1 & 0 \\
\hline
\end{tabular}

Tabel 1 merupakan jumlah blok yang terdeteksi pada objek copy-move pada pendeteksian kelompok citra palsu copy-move yang tidak dimodifikasi. Data tabel menunjukkan bahwa jumlah blok terbanyak terdeteksi pada objek copy-move adalah pada saat penggunaan blok berukuran 32×32.

Tabel 2. Hasil deteksi pada citra copy-move termodifikasi rotasi (Vertical Flipping)

\begin{tabular}{|c|c|c|c|}
\hline \multirow{2}{*}{ Citra Palsu } & \multicolumn{3}{|c|}{$\begin{array}{c}\text { Jumlah blok terdeteksi pada } \\
\text { objek copy-move (ukuran blok } \\
\text { berbeda) }\end{array}$} \\
\cline { 2 - 4 } & $64 \times 64$ & $32 \times 32$ & $16 \times 16$ \\
\hline BaracudaCopyFlid.tif & 2 & 6 & 6 \\
\hline TankCopyFlid.tif & 4 & 5 & 2 \\
\hline TrukCopyFlid.tif & 0 & 1 & 0 \\
\hline
\end{tabular}


Tabel 3. Hasil deteksi pada citra copy-move termodifikasi rotasi (Horizontal Flipping)

\begin{tabular}{|c|c|c|c|}
\hline \multirow{2}{*}{ Citra Palsu } & \multicolumn{3}{|c|}{$\begin{array}{c}\text { Jumlah blok terdeteksi pada } \\
\text { objek copy-move (ukuran blok } \\
\text { berbeda) }\end{array}$} \\
\cline { 2 - 4 } & $64 \times 64$ & $32 \times 32$ & $16 \times 16$ \\
\hline BaracudaCopyFlir.tif & 4 & 3 & 6 \\
\hline TankCopyFlir.tif & 3 & 3 & 0 \\
\hline TrukCopyFlir.tif & 0 & 1 & 0 \\
\hline
\end{tabular}

Tabel 4. Hasil deteksi pada citra copy-move termodifikasi rotasi $90^{\circ}$

\begin{tabular}{|c|c|c|c|}
\hline \multirow{2}{*}{ Citra Palsu } & \multicolumn{3}{|c|}{$\begin{array}{c}\text { Jumlah blok terdeteksi pada } \\
\text { objek copy-move (ukuran blok } \\
\text { berbeda) }\end{array}$} \\
\cline { 2 - 4 } & $64 \times 64$ & $32 \times 32$ & $16 \times 16$ \\
\hline BaracudaCopyRot.tif & 4 & 4 & 6 \\
\hline TankCopyRot.tif & 3 & 3 & 1 \\
\hline TrukCopyRot.tif & 0 & 1 & 0 \\
\hline
\end{tabular}

Tabel 2, 3 dan 4 merupakan hasil pendeteksian pada kelompok citra palsu yang telah dimodifikasi dengan operasi rotasi yaitu Horizontal Flipping, Vertical Flipping dan Rotasi $90^{\circ}$. Hasil tabel menunjukkan bahwa jumlah blok yang paling banyak terdeteksi pada objek copy-move terjadi pada citra BaracudaCopyFlir.tif, BaracudaCopyFlid.tif dan BaracudaCopyRot.tif.

Tabel 5. Hasil deteksi pada citra copy-move termodifikasi ekualisasi histogram

\begin{tabular}{|c|c|c|c|}
\hline \multirow{2}{*}{ Citra Palsu } & \multicolumn{3}{|c|}{$\begin{array}{c}\text { Jumlah blok terdeteksi pada } \\
\text { objek copy-move (ukuran blok } \\
\text { berbeda) }\end{array}$} \\
\cline { 2 - 4 } & $64 \times 64$ & $32 \times 32$ & $16 \times 16$ \\
\hline BaracudaCopyHist.tif & 1 & 1 & 0 \\
\hline TankCopyRotHist.tif & 0 & 1 & 2 \\
\hline TrukCopyHist.tif & 1 & 0 & 0 \\
\hline
\end{tabular}

Tabel 5 merupakan hasil deteksi pada kelompok citra palsu copy-move yang dimodifikasi dengan operasi ekualisasi histogram. Hasil pendeteksian menunjukkan bahwa jumlah blok yang terdeteksi pada objek copy-move sangat sedikit dibandingkan pada pendeteksian pada kelompok citra sebelumnya.

\section{KESIMPULAN}

Berdasarkan hasil yang diperoleh dari penelitian dapat diambil kesimpulan bahwa ordinal measure koefisien Discrete Cosine Transform (OM-DCT) dapat digunakan sebagai fitur untuk mendeteksi objek citra palsu pada pemalsuan citra dengan teknik copy-move. Hal ini dibuktikan dengan ditemukan blok-blok fitur pada objek citra yang dicurigai telah di-copymove yang memiliki jarak lebih kecil dari nilai ambang batas pendeteksian. Fitur ini juga mampu mendeteksi objek copy-move pada citra palsu yang dimodifikasi dengan operasi rotasi dan ekualisasi histogram. Nilai ambang batas pendeteksian yang digunakan adalah 0.4 dengan blok pendeteksian yang dipakai berukuran $64 \times$ $64,32 \times 32$ dan $16 \times 16$ piksel. Penggunaan ukuran blok pendeteksian yang berbeda-beda mempengaruhi jumlah blok yang terdeteksi pada objek copy-move menjadi lebih bervariasi.

\section{DAFTAR PUSTAKA}

[1] O. Al-Qershi dan B. Khoo, "Passive detection of copy-move forgery in digital images: State-of-the-art," Forensic Science International, Elsevier, No. 231 pp 284 - 295, Juli 2013.

[2] K. Biradjar dan H. Mankar, "Digital image forgery detection using passive techniques: A survey," Forensic Science International, Elsevier, No. 10 pp 226 245, April 2013.

[3] J. Fridrich, D. Soukal dan J. Lukas, "Detection of Copy-move in Digital Images," in: Proccedings of DFWRS 2003, Cleveland, OH, USA, 2003.

[4] J. Zhao dan J. Guo, "Passive forensics for copy-move image forgery using a method based on DCT and SVD," Forensic Science International, Elsevier, No. 233 pp 158 - 166, September 2013.

[5] C. Kim, "Content-based image copy detection," Signal Processing: Image Communication, Elsevier, No. 18 pp 169 - 184, Januari 2013.

[6] F. Arnia, K. Munadi, M. Fujiyoshi et al.,“ Improved Iris Matching Technique Using Reduced Sized of Ordinal Measure of DCT Coefficients," IEEE 17th 
International Symposium on Consumer Electronics (ISCE), pp 287-288, 2013.

[7] F. Arnia, A. Saputra dan K. Munadi, "Penggunaan Histogram Dari Koefisien Aproksimasi Wavelet Untuk Deteksi Cacat Tekstil,"Jurnal Nasional Teknik Elektro, vol:3 No. 1 Maret 2014.

[8] M. Wu, C. Lin dan C. Chang, "Image Copy Detection with Rotating Tolerance," Computational Intelligence and Security pp.464-469,2005

\section{Biodata Penulis}

Zulfan, ST, mahasiswa Program Studi Magister Teknik Elektro Program Pasca Sarjana Universitas Syiah Kuala.

Dr. Fitri Arnia, ST, M.Eng.Sc, dosen Program Studi Magister Teknik Elektro Program Pasca Sarjana Universitas Syiah Kuala.

Dr. Rusdha Muharar, ST, M.Sc, dosen Program Studi Magister Teknik Elektro Program Pasca Sarjana Universitas Syiah Kuala. 